NBER WORKING PAPER SERIES

\title{
BODY-WORN CAMERAS AND ADJUDICATION OF CITIZEN COMPLAINTS OF POLICE MISCONDUCT
}

\author{
Suat Çubukçu \\ Nusret M. Sahin \\ Erdal Tekin \\ Volkan Topalli \\ Working Paper 29019 \\ http://www.nber.org/papers/w29019
NATIONAL BUREAU OF ECONOMIC RESEARCH
1050 Massachusetts Avenue
Cambridge, MA 02138
July 2021

Kathryn Johnson provided excellent research assistance. The views expressed herein are those of the authors and do not necessarily reflect the views of the National Bureau of Economic Research.

NBER working papers are circulated for discussion and comment purposes. They have not been peer-reviewed or been subject to the review by the NBER Board of Directors that accompanies official NBER publications.

(C) 2021 by Suat Çubukçu, Nusret M. Sahin, Erdal Tekin, and Volkan Topalli. All rights reserved. Short sections of text, not to exceed two paragraphs, may be quoted without explicit permission provided that full credit, including $(\odot$ notice, is given to the source. 
Body-Worn Cameras and Adjudication of Citizen Complaints of Police Misconduct Suat Çubukçu, Nusret M. Sahin, Erdal Tekin, and Volkan Topalli

NBER Working Paper No. 29019

July 2021

JEL No. K4,K42

\begin{abstract}
Police body-worn cameras (BWCs) have been the subject of much research on how the technology's enhanced documentation of police/citizen interactions impact police behavior. Less attention has been paid to how BWC recordings affect the adjudication of citizen complaints against the police. We employ citizen complaint data from the Chicago Police Department and Civilian Office of Police Accountability filed between 2012-2020 to determine the extent to which BWC footage enhances the efficacy of evidence used to formulate a conclusion of responsibility, and whether bias against complainants based on race would subsequently be reduced. Accordingly, we exploit the staggered deployment of BWCs across 22 Chicago police districts over time to estimate the effect of BWCs on these outcomes. Our findings indicate that BWCs led to a significant decrease in the dismissal of investigations due to insufficient evidence ("not sustained") as well as a significant increase in disciplinary actions against police officers ("sustained" outcomes") with sufficient evidence to sanction their misconduct. We further find that disparities in complaints across racial groups for the "unsustained" category fade away with the implementation of BWCs.

Suat Çubukçu

Department of Justice, Law, and Criminology

School of Public Affairs

Hurst Hall 206H

American University

4400 Massachusetts Ave., NW

Washington, DC 20016-8070

suat@american.edu

Nusret M. Sahin

School of Social and Behavioral Sciences

Criminal Justice Program

Stockton University

101 Vera King Farris Dr.

Galloway, NJ 08205

Nusret.Sahin@stockton.edu

\section{Erdal Tekin}

School of Public Affairs

American University

4400 Massachusetts Avenue NW

Washington, DC 20016-8070

and IZA

and also NBER

tekin@american.edu

Volkan Topalli

Department of Criminal Justice and Criminology

Andrew Young School of Policy Studies

Georgia State University

55 Park Place \#514

Atlanta GA 30303

vtopalli@gsu.edu
\end{abstract}




\section{Introduction}

Recent sociopolitical events in the United States - particularly the Black Lives Matter movement and related calls for law enforcement accountability - have brought research on the interaction between police and citizens to the fore. A good deal of investigations in this area have shifted from research on police management of citizenry to more contemporary concepts of police accountability, emerging from the general finding that citizen trust in the police has been low, particularly among communities of color and particularly during periods of social and political upheaval (McManus et al., 2019). A key facet of this dissatisfaction stems from the extent to which police oversight of citizens has come under fire for being too harsh or biased (Bell, 2017; Smith \& Merolla, 2019). ${ }^{1}$ In the most extreme cases, citizen deaths or injury at the hands of police have garnered great attention, resulting in widespread protests and calls for legislative change. The occurrence of high-profile use of deadly force incidents against African American citizens, such as the shooting of Michael Brown in Ferguson, the death of Eric Garner in New York, and the killing of George Floyd in Minneapolis has worsened the tension between the police and African American community: In the wake of the death of George Floyd in 2020, a Gallup survey (2020) found that the level of confidence in law enforcement had dipped to was at its lowest level in the US since 1994.

Against the backdrop of such social and racial justice movements has been a consistently rising interest in the establishment of accountability processes for law enforcement, predicated on the belief of citizen activists that the police are insufficiently accountable and biased against

\footnotetext{
${ }^{1}$ African Americans in particular, are skeptical of routine policing practices and feel racially profiled by them (Warren, 2011; Horrace \& Rohlin, 2016). Several studies also found that African Americans are disproportionately targeted in stop-and-frisk practices (Meares, 2009; Lotan, 2020; NYCLU, 2012, page 5). For instance, African Americans are three to five times more likely than Whites to rate the occurrence of police misconduct as "very often” than Whites (Weitzer \& Tuch, 2004).
} 
minorities. Attempts to establish greater accountability have ranged from the social (e.g., protests) to the political (e.g., the establishment of citizen boards) to the tactical (e.g., the use of technology to objectively establish the nature of controversial police citizen interactions).

Technology, in particular, has been viewed as a potential game-changer, especially in those instances where the parties differ on what transpired during a given encounter and where there is a need to reconcile conflicting perceptions of a particular event. Receiving the most attention has been the use of body-worn cameras (BWCs) by the police. These devices are viewed by some as a panacea for the proper adjudication of police/citizen conflicts. BWCs are assumed to provide objective information about encounters between police and citizens which result in a negative outcome and where accounts of the event differ between the police and citizens (Ariel et al., 2016, 2018; Braga et al., 2017).

The implementation of BWCs is interpreted differently by these two constituencies, however. Citizens generally view the technology as providing an objective bulwark against the police officers' ability to unfairly implicate individuals in crimes or to dissemble their own involvement in criminal or unprofessional activities (White et al., 2017; Sousa et al., 2018). Police institutions (including law enforcement agencies, police unions, and police advocacy groups) have demonstrated mixed attitudes toward the blanket application of BWCs (see, Huff, et al., 2018; Nowacki \& Willits, 2018). On the one hand, those law enforcement policy-makers and decision-making constituencies who are proponents of BWC implementation see the technology as capable of either protecting their officers from unfair accusations by citizens or as a method to ensure officers conform to administrative directives, protocols, and tactics (Smykla et al., 2016; Lawshe, et al., 2019). On the other hand, individual officers and police unions generally have taken a dim view of the technology and expressed that it hinders optimal police 
decision-making. Primarily, they claim officers may be reluctant fully carry out their duties in response to concerns about potential legal action or personal safety (Phillips et al., 2020)ㄹ․ This is not surprising. Historically, police do not always embrace the adoption of technologies designed to record their activities and may be resistant to the imposition of behavioral monitoring mechanisms. In the case of BWCs, it could be expected that the cultural acceptance of this technology as 'business as usual' might take some time and effort, as would be reflected in the informal police code of conduct and police leadership's active promotion of their usage (Huff et al., 2018; Kyle \& White, 2017). At least some resistance to the release of camera footage for external review appears to be based on a police subculture known to engender insular attitudes, secrecy, and preservation of the in-group (Reiner, 2017; Quispe-Torreblanca \& Stewart, 2019) ${ }^{3}$. It's worth noting that these views are well known to the public, who view them as a lack of respect for oversight or a desire to operate outside of legal proscriptions regarding police discretion and use of force (Miethe et al., 2019).

To these ends, a great deal of research on BWC technology has focused on attitudes and opinions of law enforcement institutions, police officers, and citizens. Less studied is the technology's actual impact on the processes that drive these attitudes and beliefs, i.e., the outcomes of investigations following negative interactions between police officers and citizens. Do BWCs actually make a difference? Given the involvement of BWC videos in spurring recent

\footnotetext{
${ }^{2}$ This is in line with explanations for claims of a "Ferguson Effect," where crime rates were assumed to have increased as a result of police tamping down their enforcement engagement ("de-policing”) out of concerns that they would be held responsible for exercising discretion during encounters with the public, and an overall sense that their efforts as societal guardians were being disparaged by constituencies that did not understand the day-to-day rigors and stresses of police work (see, e.g., Nix \& Wolfe, 2018) combined with residents refraining from reporting crimes and cooperating with police due to increased mistrust (“de-legitimizing”).

${ }^{3}$ For instance, in their news article covering the New York City Police Department's (NYPD) unwillingness to share BWC footage with the Civilian Complaint Review Board (CCRB), Umansky and Simon (2020) discussed how the NYPD withheld video evidence and paper records from the CCRB in at least a couple of incidents despite the law requiring the NYPD's cooperation with the agency. They also noted that the percentage of sustained cases doubled when the investigators had access to BWC footage.
} 
protests and political actions, the extent to which they affect such outcomes in a way that addresses assumed race-based differences in police treatment of citizens has yet to be fully explored. To that end, the current paper attempts to answer a number of important, interrelated questions. First, do BWCs provide information that changes the outcome of complaint investigations? If we assume that an increase in the amount or quality of evidence improves investigative outcomes, and if we further assume that such improvements accrue to BWC-based evidence, then we would expect to see such changes reflected in actual investigation outcomes. Second, if BWC technology does provide objective information regarding police/citizen interactions, does that improvement in evidence support the claims of different categories of complainants in a way that illuminates whether there is a race effect? Here, our interest is in testing whether the racial bias claims of citizen advocates would be reflected in the outcomes of subsequent investigations. Such putatively biased outcomes could be the result of racial bias inherent in police-citizen interactions (see Taylor et al., 2009), bias in subsequent investigations and adjudication processes, or both. Put simply, if investigations of police misconduct unfairly disadvantage minorities, does BWC technology even the playing field?

To address this question, we evaluate the impact of BWC technology on the outcomes of investigations using complaint data from the Chicago Police Department between 2012-2020. Our research design exploits the staggered deployment of BWCs among 22 Chicago police districts over time to determine the extent to which evidence from BWC technology altered the outcomes of investigations in general and more specifically, whether the inclusion of BWC evidence differentiated the outcomes of police misconduct claims based on the race of complainants. Our results indicate support for the contention that before the adoption of BWCs, CPD’s citizen complaint investigations process was producing biased outcomes, and that BWC 
technology helps investigators to conduct more impartial investigations that reduce racial disparities in outcomes.

\section{The Impacts of Body-Worn Cameras on Police Behavior and Citizen Complaints}

BWCs have their origins in the implementation of police vehicle dash camera systems for enforcing motor vehicle related crimes (e.g., drunk driving) in the 1990s. The introduction of BWC technology in the mid-2000s facilitated the recording of police-citizen encounters and ushered in a new era of police accountability based on enhanced expectations by the public of “objective” evidence of what "really happens” during police-citizen encounters resulting from pervasive distribution of BWC footage on media. ${ }^{4}$ The reasons for the wide adoption of these systems in recent years reflect motivations of citizens, ${ }^{5}$ police organizations, and policy-makers, and can be summarized as follows: (1) to promote a more civilized officer and citizen behavior during encounters, (2) to evidence citizens' wrongdoing in court and to protect officers from spurious complaints, (3) to strengthen supervision and meet the public's expectations of transparency, and (4) to reduce the number of use-of-force incidents and to effectively resolve citizen complaints (Bowling \& Iyer, 2019; Coudert et al., 2015; Lum et al., 2019; Maghan et al., 2002).

The research examining the impact of BWCs on the nature of police-citizen interactions and citizen perceptions is mixed. The Rialto Randomized Controlled Trial in 2012 was the first to evaluate the causal impact of BWCs on excessive use-of-force and citizens' complaints

\footnotetext{
${ }^{4}$ Many would argue that the historical precursor for the expectation that visual footage could serve as a medium for exposing police misconduct were the "Rodney King" tapes, depicting the beating of King by members of the LAPD shot by videographer George Holliday from his balcony in 1991 (see Granot et al., 2018; Stuart, 2011). The tapes received extensive airplay in media outlets and engendered expectations of convictions for the officers involved. When they were acquitted, Los Angeles and other cities in the US experienced rioting and protests.

${ }^{5}$ The deadly shooting of Michael Brown in 2014 heightened public expectations of police accountability and both the public and the federal government urged the police in the United States to widely adopt BWCs (Bowling \& Iyer, 2019; Culhane et al., 2016). Subsequent police shootings of unarmed Black men have further intensified such expectations.
} 
against the police. In a study examining its outcomes, Ariel et al. (2015) found that deployment of BWCs led to an approximately 50 percent decrease in use-of-force incidents and a roughly 90 percent decrease in citizen complaints against officers. Furthermore, the authors concluded that the benefits of the equipment justified its costs, at a ratio of 4:1. In their follow-up work, Sutherland et al. (2017) found that the sharp reduction in the rate of complaints against Rialto police officers persisted in the three years post-experiment (page 5).

However, a recent body of work failed to support these findings, fueling skepticism. For example, in June 2015, the Washington, DC, Metropolitan Police Department partnered with policing scholars to design and execute a randomized controlled trial on BWCs in that city, with 2,224 MPD officers randomly assigned into “no BWC” or “BWC” groups. In their evaluation, Yokum et al. (2017) did not find a statistically significant effect of BWCs in reductions of useof-force incidents or citizen complaints. They concluded that adopting BWCs does not necessarily result in a change in police behavior and that law enforcement agencies should not expect significant reductions in the use-of-force or civilian complaints after their adoption. Similarly, in their systematic review of seventy BWC studies, Lum and colleagues (2019) found that more recent research on BWCs did not reveal extensive changes in officer behavior in response to camera deployment. They surmised this could be because officers are aware that BWCs provide them with evidence to refute unjustified citizen complaints. Most concerning was their conclusion that the commonly observed reductions in complaints after BWC adoption fail to persist over time (Lum et al., 2019; Koslicki et al., in press).

Meanwhile, the impact of BWC technology on citizen complaints does seem positive. For example, Jennings et al. (2015) tested the effect of BWCs on officers' response-to-resistance incidents and citizen generated complaints in a randomized controlled trial in Tampa, Florida. 
Officers allocated to the treatment group (i.e., wearing BWCs) had fewer response-to-resistance incidents and received fewer external complaints compared to those without BWCs. Another randomized controlled trial conducted by Braga and colleagues (2018) in Las Vegas, Nevada found that officers wearing BWCs received fewer use-of-force complaints and reports than those without cameras and that the resolution of citizen complaints was swifter when video evidence was made available to investigators (see also findings by Katz et al., 2014, and Groff et. al., 2020). Similarly, Peterson and Lawrence (2020) employed a panel analysis suggesting the deployment of BWCs led to fewer complaints after the deployment of the cameras, and that this drop continued over time. The question remains however, whether the decrease in citizen complaints is because of changes in police behavior (i.e., officers know they are being recorded and BWCs produce a "civilizing effect"? $)^{6}$ or because citizens are less likely to file false complaints due to the availability of video evidence.

\section{Research Context}

The Chicago Police Department and Adjudication of Citizen Complaints

The Chicago Police Department (CPD) is the second-largest municipal law enforcement agency in the United States, with 22 different police districts and more than 12,500 sworn officers as of January 2021. As is the case with other large municipalities in the US, the city has

\footnotetext{
${ }^{6}$ The assumption of a civilizing effect of BWCs on police follows a basic tenet of routine activities theory (Cohen \& Felson, 1979), where offenders (here, rule-breaking police) are assumed to be deterred from criminal behaviors (here, infractions of due process) by the presence of a capable guardian (here, video evidence). However, this assumption of accountability discounts the extent to which humans habituate to the presence of social monitoring systems or processes. In developmental psychology this effect (or the lack thereof) is a cornerstone of observational studies of parent/child interactions in the home - many of which employ camera technology - to observe family dynamics. Despite concerns that the presence of cameras would influence parents to engage in impression management (Tedeschi, 2013) with researchers by tempering their behavior toward children, research finds overwhelmingly that camera presence in the home is quickly discounted by parents via habituation and that their behavior reverts to pre-study behavior patterns, even those that would be strongly criticized for being counterproductive, overly harsh, or inappropriate (see Aspland \& Gardner, 2003; Gardner, 2000; Vuchnich, 1988). This same phenomenon has been raised as a concern with BWCs and policing (Fan, 2018; Katz, Kurtenbach, Choate \& White, 2015).
} 
a controversial history of police misconduct, disproportionately directed against the African American community (Balto, 2020). The report on the Investigation of the Chicago Police Department, published by the Department of Justice Civil Rights Division and US Attorney’s Office for the Northern District of Illinois in $2017^{7}$ highlights the role of flaws in the police accountability system on the extensive level of CPD officers' involvement in unreasonable use of force and other misconducts against citizens.

Until the Illinois State Appellate Court decided in Kalven v. the City of Chicago (2014), the information on citizen complaints against CPD members were not open to the public. In Kalven v. the City of Chicago (2014), the court ruled that the documents of citizen complaints and allegations of police misconduct are public information and should be shared under the Freedom of Information Act. Subsequently, the Invisible Institute, incorporated as a non-profit organization whose aim was to promote social and racial injustice in Chicago, created the Citizens Police Data Project's complaint level dataset based on the recorded misconduct allegations against CPD members. ${ }^{8}$ The dataset includes information on incident types, demographics of the complainant(s) and police officer(s), beat numbers, the date of complaints, and investigation outcomes.

Once the data became public, the Invisible Institute revealed that there had been 111,698 civilian complaints against CPD officers between January 2000 and June $2015^{9}$ of which only 2.1\% were sustained. Complaints were more likely to originate in neighborhoods from the south and west of the city, which are occupied by a higher proportion of minorities. Only $1.6 \%$ of Black residents' complaints were sustained between 2011 and 2015, while the overall rate of

\footnotetext{
${ }^{7}$ https://www.justice.gov/opa/file/925846/download.

${ }^{8}$ https://invisible.institute/police-data.

${ }^{9}$ The data includes information about the final findings of the investigation and information on the pending cases and cases that ended with "no findings."
} 
sustained complaints was just $2.6 \%$ during this period, suggesting a potential imbalance of investigative outcomes along racial lines. ${ }^{10}$

Investigations of Citizen Complaints

The Chicago City Council established the Civilian Office of Police Accountability (COPA) as a successor of the Independent Police Review Authority (IPRA), which had previously overseen complaints against the Chicago Police Department ${ }^{11}$. Operating independently from the CPD, its charge has been to promote police accountability ${ }^{12}$ by investigating citizen complaints against CPD members regarding, "bias-based verbal abuse, coercion, death or serious bodily injury in custody, domestic violence, excessive force, improper search and seizure, firearm discharge, taser discharge that results in death or serious bodily injury, pattern or practices of misconduct, (and) unlawful denial of access to counsel." 13 COPA has explicit authority to access all the information from the CPD and other city departments regarding ongoing investigations that fall under COPA jurisdiction including immediate access to BWC video footage related to citizen complaints against the CPD officers through Evidence.com. ${ }^{14}$

COPA intakes complaints from civilians and notifications from the members of CPD. Civilians can initiate their complaints in multiple ways, via phone, mail, the Internet, or in person at the COPA office or any CPD police station. There is no specific time limit to initiate a complaint. COPA also receives notifications from the CPD members related to firearm and taser discharge, and police custody incidents. ${ }^{15}$ Once COPA receives any complaint or notification,

\footnotetext{
${ }^{10}$ http://data.huffingtonpost.com/2015/12/chicago-officer-misconduct-allegations.

${ }^{11}$ https://www.chicagocopa.org/about-copa/mission-history/

12 https://www.chicagocopa.org/faqs/

13 https://www.chicagocopa.org/investigations/jurisdiction/

${ }^{14}$ Evidence.com is a cloud-based data storage system for BWC video footages.

15 https://www.chicagocopa.org/investigations/investigative-process/
} 
they sort and classify the allegations based on COPA and CPD’s Bureau of Internal Affairs

(BIA)'s jurisdictions. In simple terms, if the alleged misconduct harm citizens, ${ }^{16}$ the complaint goes to COPA; all other complaints of police misconducts are directed to the BIA. Within the five business days upon receiving a complaint or notification, COPA informs the complainant whether COPA or BIA will investigate the incident. ${ }^{17}$ Within the 30 days after a complaint is filed, the State of Illinois requires the complainant's signed affidavit assuring that the allegations against the members of CPD are 100\% factual. The complainant must visit the oversight agency (COPA) and sign the affidavit in-person to initiate the investigation process. ${ }^{18}$

After COPA determines that the incident falls under their jurisdiction and upon obtaining a signed affidavit from the complainant (or following the issuance of an affidavit override) ${ }^{19}$ they appoint an investigator to the case. COPA bases its investigation on the acquisition and analysis of evidence from various sources that include:

1) interviews with complainants, witnesses, and subjects; 2) relevant Department reports and other documents; 3) observations made at the scene of an incident within COPA's jurisdiction; 4) canvass of a scene to identify witnesses and other relevant evidence; 5)

\footnotetext{
${ }^{16}$ Domestic violence cases committed by police officers are also investigated by COPA.

${ }^{17}$ https://www.chicagocopa.org/investigations/investigative-process/

${ }^{18}$ Not all complaints are followed by an affidavit nor do they result in an investigation. There are several reasons for complainants not to submit an affidavit following a complaint. Signing an affidavit represents a greater commitment than the initial reporting of police misconduct. For example, complainants must sign the affidavit in person at the address of the oversight agency (i.e., COPA). Accordingly, any complainants who are time and resource constrained (e.g., lacking transportation) may fail to follow up on their initial complaint with an affidavit. Between 2012 and 2020, about 32\% of complainants did not provide a signed affidavit, and COPA dismissed them unless the oversight agency issued an affidavit override.

${ }^{19}$ The Chief Administrator of the oversight agency (COPA and IPRA) can issue an affidavit override authority considering the following circumstances: i) the nature and seriousness of the alleged misconduct; ii) the credibility, reliability, and accuracy of the information in the complaint based on COPA's knowledge of the facts and circumstances, and iii) the degree to which the alleged misconduct concerns the integrity of the officers involved or otherwise may undermine public confidence in the Department" (COPA Rules and Regulations, pages 6-7). However, the City of Chicago Office of Inspector General (OIG) reported that the oversight agencies had underused the affidavit override process.
} 
analysis of digital evidence, including audio and video recordings; 6) physical evidence; and 7) forensic analysis of evidence (COPA Rules and Regulations, page 11). ${ }^{20}$

\section{Dispositions of Adjudication}

A COPA investigation is completed with one of the following conclusions (which are featured as variables in our results, below): ${ }^{21}$

- Unfounded - where the investigation determined the allegation is false and there are no facts to support that the incident complained of actually occurred.

- Not sustained - where there are insufficient facts or evidence to determine the alleged misconduct occurred.

- Sustained - where the complainant's allegation is supported by sufficient evidence to indicate that the incident occurred, and the conduct of the officer was improper.

- Exonerated - where the evidence shows that the alleged conduct did occur but did not violate CPD policies, procedures, or training.

COPA can conclude the investigation with a 'finding' with the above four different potential outcomes. For our analysis, three categories (unfounded, not sustained, and exonerated) can be grouped as 'unsustained,' since CPD members do not receive any disciplinary actions following these three outcomes. ${ }^{22}$ The investigation can find the complaint 'sustained' when the allegation of misconduct is supported with sufficient evidence. In the case of sustained complaints, CPD members may receive a disciplinary action varying from 'violation noted' to 'separation from the department.'

\footnotetext{
${ }^{20} \mathrm{http}: / /$ www.chicagocopa.org/wp-content/uploads/2018/04/Final-COPA-Rules-and-Regulations-April-2018.pdf

${ }^{21}$ https://data.cpdp.co/glossary/.

22 The Citizens Data Project of Chicago defines “unsustained” as "a broad category of any complaints that haven't been sustained, including 'not sustained' 'unfounded' and 'exonerated.' Source: https://data.cpdp.co/glossary/.
} 
A COPA investigation may result in an outcome of "no finding" in the following dispositions: "Administratively Closed, Administratively Terminated, No Affidavit, and Within Policy OIS" (Chicago COPA, 2019). COPA can administratively close a case for various reasons, including in the case of complaints against non-CPD members, mistakenly given duplicate log number for an already initiated investigation, and the lack of signed affidavit from complainant unless the COPA administration exempts the affidavit requirement with an affidavit override

\section{Criticisms of the Investigation Process}

CPD has received criticism for their investigations of citizen complaints and lack of effective oversight on police misconduct. In their inquiry of citizen allegations against CPD members between 2011 and 2014, Faber and Kalbfeld (2019) found that IPRA, the precursor oversight agency to COPA, sustained only $5.7 \%$ of 10,077 complaints. Their analysis also revealed a racial disparity in the sustained over not-sustained cases, with White residents' complaints about ten times more likely to be found sustained than those of Black residents. Complaints from Latino residents were about 3.5 times more likely to be sustained than complaints from Black residents. Controlling for situational factors in police misconduct, race continued to be a significant factor in investigations. The pattern of racial disparity also persists when sorting out the cases with no affidavit and the investigation outcomes of allegations with an affidavit from complainants (Faber \& Kalbfeld, 2019). ${ }^{23}$

In a similar vein, the Department of Justice (DOJ) investigation report ${ }^{24}$ on the Chicago Police Department (2017) criticizes the police misconduct investigation and accountability

\footnotetext{
${ }^{23}$ They also find that police officers' race matters in investigation outcomes; complaints against White officers are less likely to be sustained than Black police officers, suggesting a systemic issue.

${ }^{24}$ https://www.justice.gov/opa/file/925846/download.
} 
process. It highlights a lack of thorough investigations on most of the complaints against CPD members and a low level of sustained complaints. According to the report, only $2 \%$ of citizen complaints led to a disciplinary sanction against police officers based on their analysis of citizen allegations made between January 2011 and June 2016. Like Faber \& Kalbfeld (2019), the DOJ report notes an extensive level of racial disproportionality in police officers' accountability for their misconduct.

\section{CPD Implementation of Police BWCs}

The CPD has kept pace with the national trend of gradually deploying BWCs for all of their patrol officers. ${ }^{25}$ The rollout was implemented on a police-district basis, with the $14^{\text {th. }}$ district the first to deploy BWCs on June $1^{\text {st }}, 2016$ for all of its patrol officers. By December 2017, all 22 CPD districts deployed BWCs for all of their 7,000 patrol officers. CPD patrol officers are required to wear BWCs during their duties and are to activate their BWCs at the beginning of any law-enforcement related incident to record its entirety, including, but not limited to: "Calls for service," "investigatory stops," "traffic stops," "traffic control," "foot and vehicle pursuits,” “arrests,” “use of force incidents,” "seizure of evidence,” "searches including searches of people, items, vehicles, buildings, and places” (City of Chicago OIG, 2019 page 28).

CPD members must inform the person(s) that they are activating their BWC and recording their interactions. CPD members cannot deactivate their BWC until the assignment is cleared, the police officer leaves the scene, or the arrestee is secured and transferred to a processing room. Also, a CPD officer may deactivate BWC recording if requested by a victim, witness of crime, or a community member who wishes to report a crime. A police officer can also deactivate the camera when they interact with a confidential informant. In such

\footnotetext{
${ }^{25}$ The BWC implementation dates for each district is given in Appendix Table 1. We obtained the CPD's BWC implementation timeline for the 22 police districts from OIG File \#18-0103 (City of Chicago OIG, 2019).
} 
circumstances, the officer must justify their deactivation with a verbal statement on the BWC before turning the camera off (pages. 28-29).

CPD members are not allowed to activate BWCs to record individuals "in residences and other private areas not open to the public and medical facilities unless there is a crime in progress and other circumstances that would allow a police officer to be lawfully present without a warrant" (page 30) in court facilities and during strip searches and daily personal activities of other police officers.

BWC Footage as Investigative Evidence

BWCs have been a major source of objective video and audio evidence for criminal investigations and adjudication of citizen complaints against police officers. Police supervisors and investigators may review BWC recordings during the resolution of citizen complaints' useof-force incidents. In addition,

"...all authorized department members and any authorized outside agency personnel have access to view recordings on the Evidence.com database...Supervisors, members of the Bureau of Internal Affairs, members of the Inspections Division, and Civilian Office of Police Accountability (COPA) investigators may view the digitally recorded footage from BWCs on Evidence.com as determined by their clearance level and as authorized by the Information Services Division" (page 33)

In the case of officer-involved shootings, recordings are mandated to be available for immediate viewing by an authorized investigation officer on Evidence.com. They are to be flagged when encounters result in a citizen complaint against a department member, detention, investigatory stops or an arrest, use of force, or the recordings have evidentiary value in a criminal investigation (page 34). 


\section{Data}

We focus on investigations on allegations of police misconduct against citizens. Specifically, our analysis considers complaints investigated by the COPA and its predecessor, IPRA. COPA and its predecessor also examine complaints about domestic violence cases committed by police officers. These cases are excluded from our analysis as our focus is the effect of BWCs on investigation outcomes for citizen complaints against police and it is unlikely that police officers use BWC during their interactions with and violence against their intimate partners. In a similar vein, the complaints that occurred while citizens are in custody are also excluded from the analysis since detention and jails are continuously monitored with mounted in-door cameras regardless of a BWC.

The dataset includes information on complaint date, basic demographics, and characteristics of complaint(s) and police officer(s), reason for complaint, investigation status (pending, review process, or closed), and investigation outcome as discussed previously. The COPA data do not include information on the district where the incident occurred. Rather, the location information is provided at the beat level. We identified the police district by matching beat assignments of police officers with district information obtained from the CPD CLEARMap (Citizen Law Enforcement Analysis and Reporting) interactive data source. ${ }^{26}$

According to the City of Chicago, Inspector of General Office's report ${ }^{27}$ on BWCs, BWCs were deployed among the CPD districts between June $1^{\text {st }}, 2016$, and December $4^{\text {th }}, 2017$. As shown in Appendix Table 1, the BWC deployment date varies among districts and this staggered implementation is key to our identification of the casual impact of BWCs on

\footnotetext{
${ }^{26}$ https://gis.chicagopolice.org

${ }^{27}$ https://igchicago.org/wp-content/uploads/2019/07/CPDs-Random-Reviews-of-Body-Worn-CameraRecordings.pdf.
} 
investigation outcomes. By matching district number, complaint date, and BWC implementation dates for districts, we generated a binary variable of whether a patrol officer(s) had a BWC during the interaction that led to a citizen complaint.

After we imposed several restrictions by excluding cases labeled as "Notification” or “Miscellaneous" and sorting out complaints with no affidavit and no finding outcomes, there remains numerous types of incidents that become the subject of complaints. The most common types of incidents are listed as "Excessive force”, "Firearm discharge”, "Verbal abuse”, “Unnecessary display of weapon”, “Civil suits”, “Coercion”, and “4 $4^{\text {th }}$ Amendment.” There are also 730 complaints filed against police officers who are allegedly involved in domestic violence. We excluded these cases from the analysis. Another 691 complaints occurred while the complaint is in custody. We also excluded these cases from the analysis since they are closely monitored regardless of the BWC. Finally, some district boundaries in Chicago had been redrawn in 2012. To maintain a consistent set of districts, we limit our empirical analysis to 2013-2020. These exclusion criteria result in an analysis sample of 2,117 complaints. The investigations of these 2,117 complaints resulted in 178 findings of “exonerated”, 856 findings of "not sustained", 422 findings of "sustained", and 661 findings of "unfounded." Our focus is the outcomes of "sustained" and "not sustained." 28

In our analysis, we control for several characteristics of the complainant as well as the police officers against whom the complaint is filed. These characteristics include indicator variables for the age, gender, and race of both the complaint and the police officer, the number of years of experience of the police officer, and an indicator variable for whether the incident

\footnotetext{
${ }^{28}$ However, we present the results for the "Exonerated" and "Unfounded" outcomes in Appendix Table 2. Note that given the small sample size for the "Exonerated" outcome, the non-parametric model for this outcome is not reliable. As shown in Appendix Table 2, there appears to be no relationship between BWC and either of these outcomes as the estimates are neither statistically significant nor sizeable.
} 
involved a police shooting. The means and standard deviations for the variables used in the analysis for the full sample as well as separately for the sub-sample with and without a BWC are reported in Table 1.

\section{Estimation Strategy}

Our baseline approach to estimating the causal relationship between BWC and the outcomes of complaint investigation exploits the temporal and spatial variation in the implementation of the BWC across Chicago police districts using a difference-in-differences framework. This approach can be expressed formally by the following regression equation:

$$
\mathrm{Y}_{\mathrm{idmy}}=\alpha_{0}+\mathrm{X}_{\mathrm{idmy}} \alpha_{1}+\alpha_{2} \mathrm{BWC}_{\mathrm{dmy}}+\delta_{\mathrm{m}}+\lambda_{\mathrm{y}}+\varphi_{\mathrm{d}}+\varepsilon_{\mathrm{idm}}
$$

where $\mathrm{Y}_{\text {idmy }}$ is a binary indicator if the investigation for the complaint $\mathrm{i}$ in district $\mathrm{d}$ month $\mathrm{m}$ and year y resulted in one of the following outcomes: exonerated, sustained, not-sustained, and

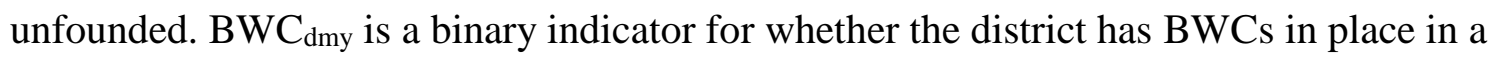
particular month and year. $X_{\text {idmy }}$ is a vector of demographic characteristics of the complainants and the police officers against whom the complaint was made, including age, race, and gender. We also control for an indicator of whether the complaint involved a police shooting. ${ }^{29}$

Equation (1) includes a series of fixed effects and trend variables to account for various types of confounding factors. Specifically, $\delta_{\mathrm{m}}$ is month fixed effects that capture any seasonality in complaints. Similarly, $\lambda_{\mathrm{y}}$ is year fixed effects that accounts for any common trends and shocks to the number of the composition of complaints that might occur at the city or national level affecting all districts. For example, any news of police misconduct captured in the national media may influence the police-citizen encounters at the district level in ways that lead to an increase in certain type of complaints. These shocks would be gauged by year fixed effects.

\footnotetext{
${ }^{29}$ Our results are not sensitive to controlling for this variable.
} 
Finally, $\varphi_{\mathrm{d}}$ represents district-fixed effects that would account for any time-invariant differences across districts. For instance, if the deployment of the BWC is correlated with some pre-existing district level factors, such as initial poverty or level of crime, then the district fixed effects would account for such factors.

It is important to note that the identification of the treatment effect in equation (1) comes from the variation in outcome categories within districts rather than comparisons between, for example, districts with a high crime rate and those with a low crime rate, or between districts with a high concentration of poverty and those districts that are more affluent. One particular advantage of using case level complaint data is that we are able control for complainant and police officer characteristics as well as characteristics of the incident such as whether a police shooting is involved. In equation (1), we compare the likelihood of a complaint investigation resulting in a particular outcome between two complainants who are identical in terms of own race and gender, the age indicators, the race, gender, and the age indicators of the police officer subject to the complaint, and whether a police shooting had occurred in the same month and year, except that one complainant is subject to the BWC policy while the other one is not. Finally, $\varepsilon_{\text {prt }}$ is the idiosyncratic error term. Finally, we cluster standard errors at the district level to account for arbitrary forms of heteroskedasticity and serial correlation within provinces over time (Bertrand et al., 2004).

Note that the empirical model specified in equation (1) imposes the assumption that the BWC effect remains constant over time. Such a specification can produce biased estimates if the effect of treatment grows stronger (or weaker) over time (Goodman-Bacon 2019). In our case, heterogeneity in the treatment effect can occur, if, for example, citizens in a particular district adjust the way in which they engage with police officers over time following the deployment of 
BWCs as they become aware of the new policy. Similarly, police officers may also change their style of engagement or adjust the way they conduct themselves when they interact with citizens. For instance, police officers could initially be extra vigilant to handle situations peacefully immediately after the deployment of BWCs, but gradually revert back to their pre-BWC style if they do not sense any detectable reactions to their behavior (Katz et al., 2015; Peterson \& Lawrence, 2020). Therefore, there are reasons to expect the relationship between BWCs and complaint outcomes to follow a non-linear pattern over time. A more flexible, non-parametric specification that allows the BWC impact to vary over time can be expressed as follows:

$$
\mathrm{Y}_{\mathrm{idmy}}=\alpha_{0}+\mathrm{X}_{\mathrm{idmy}} \alpha_{1}+\sum_{k=0}^{+5 \text { plus }} \beta_{k} \mathrm{k}_{-} \text {quarters_since_BWC } \mathrm{dmy}_{\mathrm{dm}}+\delta_{\mathrm{m}}+\lambda_{\mathrm{y}}+\varphi_{\mathrm{d}}+\varepsilon_{\mathrm{idmy}},
$$

where $k_{-} q u a r t e r s \_s i n c e \_B W C_{d m y}$ refers to a set of binary indicators, in which $k$ represents the number of quarters elapsed since the deployment of BWC (i.e., 1, 2, 3, 4, 5plus).

A causal interpretation of the BWC effects in equations (1) and (2) hinges on the "parallel trends” assumption required by the difference-in-differences method. Intuitively, this means that while there may be pre-existing differences in the prevalence of a certain outcome between districts with a BWC policy and those without one, there are no pre-existing differential trends between the two. If, for example, certain districts were experiencing an increase in the number of complaints resolved as "not sustained" prior to the deployment of the BWC relative to other districts, this would be a violation of the "parallel trends" assumption, leading to biased estimates of the effect of the BWC.

We formally test the validity of the "parallel trends" assumption by performing an eventstudy analysis that allows the BWCs to have an impact on the outcomes in the periods prior to deployment. This analysis involves estimating an augmented version of equation (2), in which both the lead and lagged values of the BWC indicator are included in the model. If the estimates 
on the lead (placebo) indicators are meaningful in the statistical sense, then we would worry that this critical assumption fails and that any effect identified in equations (1) and (2) are spuriously driven by existing differentials in trends. Appendix Table 3 reports the estimates from the eventstudy analysis for the outcomes of "not sustained" and "sustained" outcomes. As shown in the table, there is no evidence of any systematic changes in the prevalence of these outcomes in the quarters prior to the deployment of the BWC policy. In particular, all of the placebo indicators of the BWC are statistically insignificant. ${ }^{30}$

Another threat to the validity of our identification strategy is the change in the composition of individuals who file complaints against police officers. For example, it could be that individuals of a particular race or ethnicity may be more likely to file complaints or the investigations of their complaints may be more likely to result in a particular outcome. If the racial or ethnic composition of the complainants change over time in a way that is correlated with the deployment of BWCs, then the estimate on the BWCs' effect may, at least partially, reflect these racial or ethnic differences rather than the causal impact of the policy on the outcome categories. However, this would imply that citizens are aware of it when a BWC policy is in effect in their district. While we believe that this is an unlikely scenario, we address it in two ways. First, we explore the relationship between the race and ethnicity of the complainants and the presence of a BWC policy. To do so, we estimated regressions similar to those specified in equations (1) and (2), in which the outcome variable was a binary indicator reflecting the race or ethnicity of the complainant. The estimates on the BWC policies are both statistically and

\footnotetext{
${ }^{30}$ Goodman-Bacon (2020) develops an alternative method of detrending, in which he suggests estimating separate pre-treatment trends based on the timing of treatment. Then these pre-treatment trends are projected onto the posttreatment period and used to detrend the outcome variable. Our results are robust to using this alternative method of accounting for pre-trends. These results are available upon request.
} 
economically insignificant. ${ }^{31}$ Second, we later estimate our models separately by race to provide insights into the relationship between BWCs and investigation outcomes along racial and ethnic dimensions.

\section{Results}

The results from the estimation of equations (1) and (2) are presented in Table 2. Column (1) of the table shows the results for the model of the "not sustained" outcome, while the results for the model of the "sustained" outcome are shown in column (2). Panel A illustrates the results from the baseline model with a single treatment indicator as specified in equation (1) and Panel B shows the results from the non-parametric model specified in equation (2).

The estimates in Panel A of Table 2 indicate that deployment of BWC decreases the likelihood of "not sustained" finding and increases the likelihood of "sustained" finding, though only the latter is statistically significant at conventional levels. According to the point estimate, presence of a BWC is associated with a 9.9 percentage point increase in the likelihood of a "sustained" finding. Given that the mean of "sustained" finding for the non-BWC sample is 15.4 percent, this estimate translates into an effect size of approximately 64 percent.

The estimates from the non-parametric specification that allows the effect of the BWC to evolve over time are shown in Panel B. These estimates reveal that the relationship between the deployment of BWCs and complaint investigation outcomes has a time-specific pattern. Specifically, there appears to be no effect of BWCs on both "not sustained" and "sustained" findings in the first quarter following the deployment of BWCs. This is not surprising since we used complaint dates as we do not know when the incident that led to the complaint had occurred

\footnotetext{
${ }^{31}$ For example, the estimate on BWC policy is $-0.007(\mathrm{p}=0.845)$ in the model for the likelihood of the complainant being White, -0.018 ( $\mathrm{p}=0.641$ ) for the likelihood of the complainant being Black, and $-0.022(\mathrm{p}=0.851)$ for the likelihood of complainant being Hispanic.
} 
32 In the data, we match the BWC implementation dates with the complaint dates to identify whether the police had BWC during the incident. Since complaints might be filed some days after the incident took place, it is possible that some incidents, especially in the first quarters, might be coded as post-BWC deployment but occurred prior to the deployment of BWCs, and therefore no camera footage are available for them.

While there appears to be no BWC effect on either of these outcomes initially, statistically significant impacts emerge later on. For example, the presence of BWCs in a district decreases the likelihood of "not sustained" finding in the $2^{\text {nd }}$ and $3^{\text {rd }}$ quarters following the deployment as well as $5^{\text {th }}$ quarter and afterwards. Similarly, the effect on the "sustained" finding is positive for all periods after the $1^{\text {st }}$ quarter, and the point estimate is statistically significant for the $2^{\text {nd }}, 3^{\text {rd }}$, and $4^{\text {th }}$ quarters post-BWC deployment.

Taken together, the results shown in Table 2 suggests that the presence of a BWC provides information which make an investigation less likely to end with "insufficient evidence to either prove or disprove the complaint” (i.e., a not sustained finding). Furthermore, it makes an investigation more likely to result in finding "the allegation (complaint) was supported by sufficient evidence to justify disciplinary action.” (i.e., sustained).

The rates of "not sustained” and "sustained” findings exhibit significant differences across complainant race and ethnicity. For example, prior to BWC deployment, complaint investigations are much more likely have a finding of "not sustained” for Black complainants (53 percent) and Hispanic complainants (50 percent) compared to White complainants (38 percent). Similarly, White complainants have a much higher prevalence of having a sustained finding (21

\footnotetext{
${ }^{32}$ Our conversations with the COPA officials indicated that the average duration of time from a misconduct incident and filing of a complaint is 11 days. To assess the sensitivity of our results to this misalignment in some of our observations, we re-estimated our models excluding the observations within 10, 20, 30, and 45 days of the introduction of BWCs. These results are very similar to those presented in Table 2.
} 
percent) compared to Black complainants (10 percent) and Hispanic complainants (14 percent) prior to BWC deployment. According to descriptive statistics, the disparities in "not sustained" findings largely disappeared following the deployment of BWCs. The prevalence of "not sustained” findings after BWCs is 16 percent among White complainants, 18 percent among Black complainants, and 15 percent among Hispanic complainants. Concerning the "sustained" finding, it appears that the presence of a BWC helps investigation of cases regardless of complainant's race and ethnicity. In the post-BWC period, the sample means for "sustained" complaints goes up to 45 percent among White complainants, 31 percent among Black complainants, and 27 percent among Hispanic complainants. While these patterns are informative of the role that BWCs might have played in reducing racial and ethnic disparities in investigation outcomes, they are based on raw statistics that are not adjusted for other differences among complainants as well as the differences in the characteristics of police officers against whom the complaints are filed. To adjust for these differences, we estimated an augmented version of equation (1) in which we interact the BWC indicator with race and ethnicity of the complainant. ${ }^{33}$ The results from this model are shown in Table 3. As illustrated in the table, Black and Hispanic complainants are more likely to face an investigation finding of "not sustained" and less likely to face the outcome of "sustained" compared to White complainants. The interaction term between BWC indicator and Black complainant in column 1 indicates that BWCs reduce the likelihood of a "not sustained" finding by about 16.2 percentage point among Blacks and Hispanics compared to White complainants, though only the estimate on the Black complainant interaction is statistically significant at conventional levels. This evidence is

\footnotetext{
${ }^{33}$ It is not straightforward to interpret the interaction terms in the non-parametric model specified by equation (2). To keep it tractable, we only consider an augmented version of equation (1) in which we interact BWC with race and ethnicity of the complainants.
} 
consistent with the descriptive statistics discussed above and lends further support for the contention that the presence of a BWC helps eliminate ambiguities of conflicting accounts in the complaints of Black and Hispanic complainants more than it does for White complainants, resulting in the narrowing of disparities along racial lines. Regarding the outcome of "sustained", the emerging picture from Table 3 is less clear. The estimates on the interaction terms for Black and Hispanic complainants are both small and neither are statistically significant, suggesting that the impact of BWCs on the "sustained" finding for Black and Hispanic complainants does not differ from that of White complainants. That said, it is important to stress that these estimates do not imply that BWCs fail to help the cases of Black and Hispanic complainants. On the contrary, they suggest that they are equally beneficial for all racial groups. This is because the estimate on the first row represents the impact of BWCs on the likelihood of "sustained" finding among White complainants, which has a positive sign though not statistically significant.

\section{Conclusions and Discussion}

We explored the role of BWC technology in adjudicating the outcome of investigations involving citizen complaints against the police. Our analytic strategy was predicated on determining whether the availability of BWC footage enhances the efficacy of evidence used to formulate a conclusion of responsibility, and on whether racial disparities in the outcomes of complaint investigations would subsequently be reduced. Regarding the former, the notion that BWC footage introduces an objective enhancement to investigations of citizen complaints is demonstrated in our analysis by the decrease in "not sustained" findings and the concomitant increase in "sustained" findings (by roughly 10\%). Recall that "not sustained" findings mean there is "insufficient evidence to either prove or disprove the complaint" and that "sustained" findings mean "the allegation (complaint) was supported by sufficient evidence to justify 
disciplinary action.” Thus, the drop in "not sustained" versus the rise in "sustained” findings resulting from BWC policy implementation supports the notion that BWC footage provides objective and less controvertible evidence for investigations, helping them clear the bar for identifying whether an officer has engaged in an infraction or not.

How does this putative increase in the accuracy of adjudication outcomes influence our understanding of race effects in complaints against the police? If claims of racial bias are accurate, we would expect an improvement in adjudication outcomes for minorities in particular. In fact, the pattern of results supports this hypothesis. Disparities in complaints across racial groups for the "not sustained" findings disappear with the deployment of BWCs. That said, initial analyses show "sustained" findings increased across the board following BWC deployment, but with persistent disparities across race, with White complainants receiving the highest percentage of sustained findings and Black complainants the lowest, albeit higher than pre-BWC levels. This finding is tempered however by our analysis on the interaction between BWC and Black complainant, which shows that the implementation of BWC technology reduces the likelihood of "not sustained" finding among Black and Hispanic complainants compared to White complainants.

The suggestion here is that while Black complainants are taken less seriously and White complainants are taken more seriously (in line with extant research on citizen complaints and race; see Terrill \& Ingram, 2016), the presence of BWC technology serves to even the playing field by introducing objective evidence into the investigation process. In other words, Black complainants were not given the same level of consideration as White complainants before the deployment of BWCs in Chicago, and BWC technology is an effective tool in minimizing the racial disparity in citizen complaint investigation outcomes. 
As BWCs have strong potential to provide enhanced documentation of police and citizen behaviors and situational factors during a citizen and police interaction, this technology can provide visual and audio evidence to help investigators objectively assess police misconduct allegations. It is especially important when police officers dispute the complainants' allegations, and there are no witnesses to confirm or deny their statements. Even so, there may be cases where police officers may bring counterarguments against citizens and make claims against citizens for misdemeanors, such as resisting or obstructing an officer, or physical assault on of an officer. It can be quite challenging for the investigators to distinguish truth from falsehood when police officers and citizens make contradictory statements. In these cases, the video footages can provide critical objective information about the incident and the credibility of police officers' and complainants' statements. By viewing the video footages, the investigators can identify additional witnesses, who can bring additional information about the interaction and alleged police misconduct.

Our analysis is not without limitations and caveats. For example, the data for this analysis allow us to assess whether a BWC was available during the police and citizen interaction, however, it does not provide information on whether the incident was properly captured (despite the mandatory policies requiring police officers to turn on their BWCs during citizen interactions) with a few exceptions. Consequently, our conclusions regarding the benefits of BWC technology as a tool to improve outcomes, especially in terms of resolving race-based disparities regarding the adjudication of investigative outcomes, should be interpreted with that limitation in mind. Moreover, even in a citizen interaction in which footage is available, the video captured may not include potentially pertinent information for an effective investigation. Given the extent to which citizens assume high efficacy of BWCs, this too must be considered, 
especially when contextualizing what BWC footage can and cannot accomplish in terms of adjudication outcomes.

There are a variety of logistical and operational challenges related to the incorporation of BWC footages in the resolution process for complaints. As the proportion of officers with BWCs grows over time, there are bound to be challenges involved in assessing the video footage associated with a complaint. Even though COPA investigators have authority to access BWC video footage, they may need assistance from the CPD to pinpoint the relevant videos and integrate them into the investigation and adjudication process. This may jeopardize the desired independent nature of investigations and corrode confidence in the process overall. It's important for COPA to provide technical and logistical support to investigators in their efforts to seek and incorporate BWC video evidence into the investigation. Easy access to BWC videos could improve the adjudication process further.

Despite the above-mentioned challenges, our research provides practitioners with evidence of the effectiveness of these systems in minimizing racial disparity in responses to citizen complaints and facilitating misconduct investigations by visualizing the incident. The role of race on dispositional outcomes in police misconduct cases has been addressed in a handful of studies, the majority of which find that an allegation is less likely to be "Sustained" when the complainant is a minority group member (Headley et al., 2017; Pate \& Fridell, 1993; Terrill \& Ingram, 2016). Furthermore, minority complainants might be afforded less credibility in the absence of BWC footage as some police officers may have perceptions of minority community members as "lawless” or “troublemakers” (Sahin, 2014; Weitzer \& Tuch, 2004). Our research suggests that BWCs have an impact on closing the Black-White citizen gap in police misconduct investigations. 
People living in minority communities complain that they are subject to biased and aggressive policing practices (Brooks, 2000). In addition to personal and vicarious experiences, highly publicized police misconduct incidents in minority communities are disseminated through social media and blog posts, news stories, and video sharing platforms. Both feed perceptions of biased policing among minority communities (Evans \& Williams, 2017; Ray et al., 2017; Warren, 2011) making the task of policing far more difficult. These perceptions could possibly be altered through effective and transparent police misconduct investigations. The employment of BWC footage for investigating misconduct allegations and disciplining wrongdoers could help agencies address citizen expectations of impartial and accountable policing and improve confidence in the motivations and performance of police as impartial societal guardians. 


\section{References}

Ariel, B., Farrar, W. A., \& Sutherland, A. (2015). The effect of police body-worn cameras on use of force and citizen's complaints against the police: A randomized controlled trial. Journal of Quantitative Criminology, 31, 509-535.

Ariel, B., Sutherland, A., Henstock, D., Young, J., Drover, P., Sykes, J., ... \& Henderson, R. (2016). Report: Increases in police use of force in the presence of body-worn cameras are driven by officer discretion: A protocol-based subgroup analysis of ten randomized experiments. Journal of experimental criminology, 12(3), 453-463.

Ariel, B., Sutherland, A., Henstock, D., Young, J., Drover, P., Sykes, J., Megicks, S., \& Henderson, R. (2018). Paradoxical effects of self-awareness of being observed: Testing the effect of police body-worn cameras on assaults and aggression against officers. Journal of Experimental Criminology. 12, 19-47.

Aspland, H., \& Gardner, F. (2003). Observational measures of parent-child interaction: An introductory review. Child and Adolescent Mental Health, 8(3), 136-143.

Balto, S. (2020). Occupied territory. The University of North Carolina Press.

Bell, M. C. (2017). Police reform and the dismantling of legal estrangement. The Yale Law Journal, 126(7), 2054-2150.

Bertrand, M., Duflo, E., \& Mullainathan, S. (2004). How much should we trust differences-indifferences estimates? The Quarterly Journal of Economics, 119(1), 249-275.

Bowling, B., \& Iyer, S. (2019). Automated policing: The case of bod-worn video. International Journal of Law in Context, 15(2), 140-161.

Braga, A. A., Coldren, Jr., J. R., Sousa, W. H., Rodriquez, D., \& Alper, O. (2017). The Las Vegas body-worn camera experiment: Research summary. UNLV Center for Crime and Justice Policy.

Braga, A. A., Sousa, W. H., Coldren, Jr., J. R., \& Rodriguez, D. (2018). The effects of bodyworn cameras on police avticity and police-citizen encounters: A randomized controlled trial. Criminology, 108(3), 511-538.

Brooks, R. R. W. (2000). Fear and fairness in the city: Criminal enforcement and perceptions of fairness in minority communities. Southern California Law Review, 73, 1219-1273.

City of Chicago Civilian Office of Police Accountability. (2018). Civilian Office of Police Accountability rules and regulations. http://www.chicagocopa.org/wpcontent/uploads/2018/04/Final-COPA-Rules-and-Regulations-April-2018.pdf. 
City of Chicago Civilian Office of Police Accountability. (n.d.). FAQS.

https://www.chicagocopa.org/faqs/.

City of Chicago Civilian Office of Police Accountability. (n.d.). Vision and mission. https://www.chicagocopa.org/about-copa/mission-history/.

City of Chicago Civilian Office of Police Accountability. (n.d.). Jurisdiction. https://www.chicagocopa.org/investigations/jurisdiction/.

City of Chicago Civilian Office of Police Accountability. (n.d.). Investigative process. https://www.chicagocopa.org/investigations/investigative-process/

City of Chicago Office of Inspector General. (2019 July). Evaluation of the Chicago Police Department's random reviews of body-worn camera recordings. https://igchicago.org/wpcontent/uploads/2019/07/CPDs-Random-Reviews-of-Body-Worn-Camera-Recordings.pdf.

Chicago Police Department. (n.d.). Chicago Police Department CLEARMap. https://gis.chicagopolice.org/.

Coudert, F., Butin, D., \& Le Metayer, D. (2015). Body-worn cameras for police accountability: Opportunities and risks. Computer Law \& Security Review, 31(6), 749-762.

Cohen, L. E., \& Felson, M. (1979). Social change and crime rate trends: A routine activity approach. American Sociological Review, 44(4), 588-608.

Culhane, S. E., Bowman, IV, J. H., \& Schweitzer, K. (2016). Public perceptions of the justifiability of police shootings: The role of body cameras in a pre- and post-Ferguson experiment. Police Quarterly, 19(3), 251-274.

Evans, D. N., \& Williams, C.-L. (2017). Stop, question, and frisk in New York City: A study of public opinions. Criminal Justice Policy Review, 28(7), 687-709.

Faber, J. W., \& Kalbfeld, J. R. (2019). Complaining while Black: Racial disparities in the adjudication of complains against the police. City \& Community, 18(3), 1028-1067.

Gallup, I. (2020, August 12). Amid Pandemic, Confidence in Key U.S. Institutions Surges. Gallup.Com. https://news.gallup.com/poll/317135/amid-pandemic-confidence-key-institutionssurges.aspx

Gardner, F. (2000). Methodological issues in the direct observation of parent-child interaction: Do observational findings reflect the natural behavior of participants? Clinical Child and Family Psychology Review, 3(3), 185-198.

Granot, Y., Balcetis, E., Feigenson, N., \& Tyler, T. (2018). In the eyes of the law: Perception versus reality in appraisals of video evidence. Psychology, Public Policy, and Law, 24(1), 93104. 
Groff, E., Haberman, C., \& Wood, J. (2020). The effects of body-worn cameras on police-citizen encounters and police activity: evaluation of a pilot implementation in Philadelphia, PA. Journal of Experimental Criminology, 16, 463-480.

Headley, A. M., D’Alessio, S. J., \& Stolzenberg, L. (2017). The effect of a complainant's race and ethnicity on dispositional outcome in police misconduct cases in Chigaco. Race and Justice, 10(1), 43-61.

Hinds, L. (2009). Public satisfaction with police: The influence of general attitudes and policecitizen encounters. International Journal of Police Science \& Management, 11(1), 54-66.

Hollis, M. E., \& Jennings, W. G. (2018). Racial disparities in police use-of-force: a state-of-theart review. Policing: An International Journal, 41(2), 178-193

Horrace, W. C., \& Rohlin, S. M. (2016). How dark is dark? Bright lights, big city, racial profiling. Review of Economics and Statistics, 98(2), 226-232.

Huff, J., Katz, C. M., \& Webb, V. J. (2018). Understanding police officer resistance to bodyworn cameras. Policing: An International Journal, 41(4), 482-495.

Jennings, W. G., Lynch, M. D., \& Fridell, L. A. (2015). Evaluating the impact of police officer body-worn cameras (BWCs) on response-to-resistance and serious external complaints: Evidence from the Orland police department (OPD) experience utilizing a randomized controlled experiment. Journal of Criminal Justice, 43(6), 480-486.

Kalven v. The City of Chicago, 2014 Ill. App. (1st) 121846.

Katz, C. M., Choate, D. E., Ready, J. R., \& Nuno, L. (2014). Evaluating the Impact of Officer Worn Body Cameras in the Phoenix Police Department. Phoenix, AZ: Center for Violence Prevention \& Community Safety, Arizona State University. Stable url: https://www.researchgate.net/publication/282981216_Evaluating_the_Impact_of_Officer_Worn Body_Cameras_in_the_Phoenix_Police_Department.

Koslicki, W. M., Lytle, D. J., Willits, D. W., \& Brooks, R. (in press). 'Rhetoric without reality' or effective policing strategy? An analysis of the relationship between community policing and police fatal force. Journal of Criminal Justice.

Kyle, M. J., \& White, D. R. (2017) The impact of law enforcement officer perceptions of organizational justice on their attitudes regarding body-worn cameras. Journal of Crime and Justice, 40(1), 68-83.

Lawshe, N. L., Burruss, G. W., Giblin, M. J., \& Schafer, J. A. (2019). Behind the lens: police attitudes toward body-worn cameras and organizational justice. Journal of Crime and Justice, 42(1), 78-97. 
Lotan, G. T. (June 15, 2020). Data show Boston police stop Black people most often. Boston Globe. Stable url: https://www.bostonglobe.com/2020/06/15/metro/data-show-boston-policestop-black-people-most-often/.

Lum, C., Stoltz, M., Koper, C. S., \& Scherer, J. A. (2019). Research on body-worn cameras: What we know, what we need to know. Criminology \& Public Policy, 18(1), 93-118.

Maghan, J., O’Reilly, G. W., \& Shon, P. C. H. (2002). Technology, Policing, and Implications of in-car videos. Police Quarterly, 5(1), 25-42.

Mastrofski, S. D. (2004). Controlling street-level police discretion. The Annals of the American Academy of Political and Social Science, 593(1), 100-118.

McManus, H. D., Graham, A., Cullen, F. T., Burton Jr, V. S., \& Jonson, C. L. (2019). Friend not foe? Reconsidering race, the police, and community relations. Race and Justice, Article 2153368719849486.

Meares, T. (2009). The legitimacy of police among young African-American men. Marquette Law Review, 92(4), 651-666.

Miethe, T. D., Lieberman, J. D., Heen, M. S., \& Sousa, W. H. (2019). Public attitudes about body-worn cameras in police work: A national study of the sources of their contextual variability. Criminal Justice Review, 44(3), 263-283.

New York Civil Liberties Union. (2012). Stop and frisk 2012. https://www.nyclu.org/sites/default/files/publications/2012_Report_NYCLU_0.pdf.

Nix, J., \& Wolfe, S. E. (2018). Management-level officers' experiences with the Ferguson effect. Policing: An International Journal, 41(2), 262-275.

Nowacki, J. S., \& Willits, D. (2018). Adoption of body cameras by United States police agencies: an organisational analysis. Policing and Society, 28(7), 841-853.

Pate, A. M., \& Fridell, L. A. (1993). Police use of force: Official reports citizen complaints, and legal consequences. Police Foundation, Washington D.C. stable url:

https://www.ojp.gov/pdffiles1/Digitization/146825NCJRS.pdf.

Peterson, B. E., \& Lawrence, D. S. (2020). Do the effects of police body-worn cameras on use of force and complaints change over time? Results from a panel analysis in the Milwaukee police department. Criminal Justice and Behavior, 48960, 734-754.

Phillips, S. W., Kim, D.-Y.,\& Gramaglia, J. (2020). The impact of general police officer outlooks on their attitudes toward body-worn cameras. Policing: An International Journal, 43(3), 451-467. 
Quispe-Torreblanca, E. G., \& Stewart, N. (2019). Causal peer effects in police misconduct. Nature Human Behaviour, 3(8), 797-807.

Ray, R., Brown, M., Fraistat, N., \& Summers, E. (2017). Ferguson and the death of Michael Brown on Twitter: \#BlackLivesMatter, \#TCOT, and the evolution of collective identities. Ethnic and Racial Studies, 40(11), 1797-1813.

Reiner, R. (2017). Is police culture cultural?. Policing: A Journal of Policy and Practice, 11(3), 236-241.

Sahin, N. M. (2014). Legitimacy, procedural justice, and police-citizen encounters: A randomized controlled trial of the impact of procedural justice on citizen perceptions of the police during traffic stops in Turkey. Rutgers University.

Smith, J. P., \& Merolla, D. M. (2019). Black, blue, and blow: the effect of race and criminal history on perceptions of police violence. Sociological Inquiry, 89(4), 624-644.

Smykla, J. O., Crow, M. S., Crichlow, V. J., \& Snyder, J. A. (2016). Police body-worn cameras: Perceptions of law enforcement leadership. American Journal of Criminal Justice, 41(3), 424 443.

Sousa, W. H., Miethe, T. D., \& Sakiyama, M. (2018). Inconsistencies in public opinion of bodyworn cameras on police: Transparency, trust, and improved police-citizen relationships. Policing: A Journal of Policy and Practice, 12(1), 100-108.

Stuart, F. (2011). Constructing police abuse after Rodney King: How skid row residents and the Los Angeles Police Department contest video evidence. Law \& Social Inquiry, 36(2), 327-353.

Sutherland, A., Ariel, B., Farrar, W., \& De Anda, R. (2017). Post-experimental follow-upsFade-out versus persistence effects: The Rialto police body-worn camera experiment four years on. Journal of Criminal Justice, 53, 110-116.

Taylor, T. J., Holleran, D., \& Topalli, V. (2009). Racial bias in case processing: Does victim race affect police clearance of violent crime incidents? Justice Quarterly, 26(3), 562-591.

Tedeschi, J. T. (Ed.). (2013). Impression management theory and social psychological research. Academic Press.

Terrill, W., \& Ingram, J. R. (2016). Citizen complaints against the police: An eight city examination. Police Quarterly, 19(2), 150-179.

Umansky, E., \& Simon, M. (2020). The NYPD is withholding evidence from investigations into police abuse. Propublica. https://www.propublica.org/article/the-nypd-is-withholding-evidencefrom-investigations-into-police-abuse. 
United States Attorney's Office Northern District of Illinois. (2017). Investigation of the Chicago Police Department. United States Department of Justice, Civil Rights Division. https://www.justice.gov/opa/file/925846/download.

Vuchinich, S., Emery, R. E., \& Cassidy, J. (1988). Family members and third parties in dyadic family conflict: Strategies, alliances, and outcomes. Child Development, 59(5), 1293-1302.

Warren, P.Y. (2011). Perceptions of police disrespect during vehicle stops: A race-based analysis. Crime \& Delinquency, 57(3), 356-376.

Weitzer, R., \& Tuch, S. A. (2004). Race and perceptions of police misconduct. Social Problems, 51(3), 305-325.

White, M. D., Todak, N., \& Gaub, J. E. (2017). Assessing citizen perceptions of body-worn cameras after encounters with police. Policing: An International Journal, 40(4), 689-703..

Yokum, D., Ravishankar, A., \& Coppock, A. (October 20, 2017). Evaluating the effects of police body-worn cameras: A randomized controlled trial. Working Paper. The Lab @ DC. Stable url: https://discover.pbcgov.org/criminaljustice/BodyWorn\%20Camera\%20Clearinghouse/TheLabD C_MPD_BWC_Working_Paper_10.20.17.pdf.

Zhao, J. S., Schneider, M., \& Thurman, Q. (2002). The effect of police presence on public fear reduction and satisfaction: A review of the literature. The Justice Professional, 15(3), 273-299. 
Table 1: Descriptive Statistics

\begin{tabular}{|c|c|c|c|}
\hline Variable & Full Sample & $\mathrm{BWC}=0$ & $\mathrm{BWC}=1$ \\
\hline Not Sustained & $\begin{array}{l}0.404 \\
(0.491)\end{array}$ & $\begin{array}{l}0.486 \\
(0.500)\end{array}$ & $\begin{array}{l}0.168 \\
(0.374)\end{array}$ \\
\hline Sustained & $\begin{array}{l}0.199 \\
(0.400)\end{array}$ & $\begin{array}{l}0.154 \\
(0.361)\end{array}$ & $\begin{array}{l}0.330 \\
(0.471)\end{array}$ \\
\hline Exonerated & $\begin{array}{l}0.084 \\
(0.278)\end{array}$ & $\begin{array}{l}0.028 \\
(0.165)\end{array}$ & $\begin{array}{l}0.247 \\
(0.432)\end{array}$ \\
\hline Unfounded & $\begin{array}{l}0.312 \\
(0.464)\end{array}$ & $\begin{array}{l}0.332 \\
(0.471)\end{array}$ & $\begin{array}{l}0.255 \\
(0.436)\end{array}$ \\
\hline BWC & $\begin{array}{l}0.256 \\
(0.437)\end{array}$ & 0 & 1 \\
\hline Male Complainant & $\begin{array}{l}0.630 \\
(0.483)\end{array}$ & $\begin{array}{l}0.622 \\
(0.485)\end{array}$ & $\begin{array}{l}0.653 \\
(0.476)\end{array}$ \\
\hline Female Complainant & $\begin{array}{l}0.0221 \\
(0.415)\end{array}$ & $\begin{array}{l}0.222 \\
(0.416)\end{array}$ & $\begin{array}{l}0.218 \\
(0.413)\end{array}$ \\
\hline Male and Female Complainant & $\begin{array}{l}0.088 \\
(0.283)\end{array}$ & $\begin{array}{l}0.097 \\
(0.296)\end{array}$ & $\begin{array}{l}0.061 \\
(0.239)\end{array}$ \\
\hline White Complainant & $\begin{array}{l}0.088 \\
(0.284)\end{array}$ & $\begin{array}{l}0.094 \\
(0.293)\end{array}$ & $\begin{array}{l}0.070 \\
(0.256)\end{array}$ \\
\hline Black Complainant & $\begin{array}{l}0.685 \\
(0.465)\end{array}$ & $\begin{array}{l}0.667 \\
(0.471)\end{array}$ & $\begin{array}{l}0.736 \\
(0.096)\end{array}$ \\
\hline Hispanic Complainant & $\begin{array}{l}0.121 \\
(0.326)\end{array}$ & $\begin{array}{l}0.132 \\
(0.339)\end{array}$ & $\begin{array}{l}0.089 \\
(0.284)\end{array}$ \\
\hline Mixed Race Complainant & $\begin{array}{l}0.088 \\
(0.283)\end{array}$ & $\begin{array}{l}0.087 \\
(0.281)\end{array}$ & $\begin{array}{l}0.096 \\
(0.295)\end{array}$ \\
\hline Age of Complainant=0-19 & $\begin{array}{l}0.099 \\
(0.298)\end{array}$ & $\begin{array}{l}0.119 \\
(0.324)\end{array}$ & $\begin{array}{l}0.041 \\
(0.198)\end{array}$ \\
\hline Age of Complainant=20-29 & $\begin{array}{l}0.241 \\
(0.428)\end{array}$ & $\begin{array}{l}0.245 \\
(0.430)\end{array}$ & $\begin{array}{l}0.231 \\
(0.421)\end{array}$ \\
\hline Age of Complainant=30-39 & $\begin{array}{l}0.219 \\
(0.414)\end{array}$ & $\begin{array}{l}0.206 \\
(0.405)\end{array}$ & $\begin{array}{l}0.258 \\
(0.438)\end{array}$ \\
\hline Age of Complainant=40-49 & $\begin{array}{l}0.143 \\
(0.350)\end{array}$ & $\begin{array}{l}0.134 \\
(0.341)\end{array}$ & $\begin{array}{l}0.170 \\
(0.376)\end{array}$ \\
\hline Age of Complainant=50-59 & $\begin{array}{l}0.070 \\
(0.256)\end{array}$ & $\begin{array}{l}0.060 \\
(0.237)\end{array}$ & $\begin{array}{l}0.101 \\
(0.302)\end{array}$ \\
\hline Age of Complainant=70+ & $\begin{array}{l}0.008 \\
(0.089)\end{array}$ & $\begin{array}{l}0.006 \\
(0.075)\end{array}$ & $\begin{array}{l}0.015 \\
(0.121)\end{array}$ \\
\hline Male Police Officer & $\begin{array}{l}0.704 \\
(0.457)\end{array}$ & $\begin{array}{l}0.695 \\
(0.461)\end{array}$ & $\begin{array}{l}0.731 \\
(0.444)\end{array}$ \\
\hline Female Police Officer & $\begin{array}{l}0.075 \\
(0.263)\end{array}$ & $\begin{array}{l}0.071 \\
(0.257)\end{array}$ & $\begin{array}{l}0.085 \\
(0.279)\end{array}$ \\
\hline Male and Female Police Officer & $\begin{array}{l}0.110 \\
(0.314)\end{array}$ & $\begin{array}{l}0.091 \\
(0.287)\end{array}$ & $\begin{array}{l}0.168 \\
(0.374)\end{array}$ \\
\hline White Police Officer & $\begin{array}{l}0.313 \\
(0.464)\end{array}$ & $\begin{array}{l}0.328 \\
(0.470)\end{array}$ & $\begin{array}{l}0.269 \\
(0.444)\end{array}$ \\
\hline Black Police Officer & $\begin{array}{l}0.168 \\
(0.374)\end{array}$ & $\begin{array}{l}0.173 \\
(0.336)\end{array}$ & $\begin{array}{l}0.153 \\
(0.360)\end{array}$ \\
\hline Hispanic Police Officer & 0.130 & 0.130 & 0.132 \\
\hline
\end{tabular}




\begin{tabular}{|c|c|c|c|}
\hline \multirow{3}{*}{ Mixed Race Police Officer } & $(0.337)$ & $(0.336)$ & $(0.340)$ \\
\hline & 0.261 & 0.210 & 0.408 \\
\hline & $(0.439)$ & $(0.408)$ & $(0.189)$ \\
\hline \multirow[t]{2}{*}{ Age of Police Officer=20-29 } & 0.038 & 0.030 & 0.063 \\
\hline & $(0.192)$ & $(0.170)$ & $(0.243)$ \\
\hline \multirow[t]{2}{*}{ Age of Police Officer =30-39 } & 0.231 & 0.252 & 0.168 \\
\hline & $(0.421)$ & $(0.434)$ & $(0.374)$ \\
\hline \multirow[t]{2}{*}{ Age of Police Officer =40-49 } & 0.210 & 0.228 & 0.157 \\
\hline & $(0.407)$ & $(0.420)$ & $(0.364)$ \\
\hline \multirow{2}{*}{ Age of Police Officer =50-59 } & 0.078 & 0.077 & 0.079 \\
\hline & $(0.268)$ & $(0.267)$ & $(0.271)$ \\
\hline \multirow[t]{2}{*}{ Age of Police Officer =60-69 } & 0.004 & 0.003 & 0.006 \\
\hline & $(0.061)$ & $(0.056)$ & $(0.074)$ \\
\hline \multirow[t]{2}{*}{ Number of Years of Service of Police Officer=0-4 } & 0.132 & 0.098 & 0.231 \\
\hline & $(0.339)$ & $(0.298)$ & $(0.422)$ \\
\hline \multirow[t]{2}{*}{ Number of Years of Service of Police Officer=5-9 } & 0.109 & 0.126 & 0.061 \\
\hline & $(0.312)$ & $(0.332)$ & $(0.239)$ \\
\hline \multirow[t]{2}{*}{ Number of Years of Service of Police Officer=10-14 } & 0.123 & 0.138 & 0.079 \\
\hline & $(0.329)$ & $(0.345)$ & $(0.271)$ \\
\hline \multirow{2}{*}{ Number of Years of Service of Police Officer=15-19 } & 0.097 & 0.107 & 0.070 \\
\hline & $(0.296)$ & $(0.309)$ & $(0.256)$ \\
\hline \multirow[t]{2}{*}{ Number of Years of Service of Police Officer=20-24 } & 0.069 & 0.070 & 0.068 \\
\hline & $(0.254)$ & $(0.255)$ & $(0.252)$ \\
\hline \multirow[t]{2}{*}{ Number of Years of Service of Police Officer=25-29 } & 0.026 & 0.021 & 0.039 \\
\hline & $(0.158)$ & $(0.143)$ & $(0.193)$ \\
\hline \multirow[t]{2}{*}{ Number of Years of Service of Police Officer $=30+$} & 0.001 & 0.002 & 0.000 \\
\hline & $(0.038)$ & $(0.044)$ & $(0.000)$ \\
\hline \multirow[t]{2}{*}{ Complaint Involves Police Shooting } & 0.017 & 0.019 & 0.009 \\
\hline & $(0.128)$ & $(0.137)$ & $(0.096)$ \\
\hline Number of Observations & 2,117 & 1,575 & 542 \\
\hline
\end{tabular}


Table 2: Estimates of the Effect of Body Worn Cameras on Complaint Outcomes

\begin{tabular}{cll}
\hline & Not Sustained & Sustained \\
\hline Panel A & & \\
\hline \multirow{2}{*}{ BWC } & & \\
& -0.055 & $0.099^{*}$ \\
& $(0.054)$ & $(0.052)$ \\
\hline
\end{tabular}

Panel B

$\begin{array}{lll}1 \text { quarter post BWC } & 0.015 & -0.046 \\ & (0.099) & (0.098) \\ 2 \text { quarters post BWC } & -0.122^{*} & 0.210^{* *} \\ & (0.069) & (0.090) \\ 3 \text { quarters post BWC } & -0.169 * * * & 0.151^{*} \\ & (0.050) & (0.085) \\ 4 \text { quarters post BWC } & -0.001 & 0.202^{* *} \\ 5 \text { or more quarters post BWC } & (0.074) & (0.076) \\ & -0.112^{*} & 0.098 \\ & (0.063) & (0.077)\end{array}$

Number of Observations

2,117

2,117

Notes: Robust standard errors clustered at the district level are in parentheses. *, **, and ${ }^{* * *}$ indicate statistical significance at the 10 percent, 5 percent, and 1 percent levels, respectively. 
Table 3: Estimates of the Effect of Body Worn Cameras on Complaint Outcomes by Race and Ethnicity

\begin{tabular}{lll}
\hline Variable & Not Sustained & Sustained \\
\hline BWC & 0.071 & 0.125 \\
& $(0.092)$ & $(0.102)$ \\
Black Complainant & $0.165^{* * *}$ & $-0.112^{* * *}$ \\
& $(0.051)$ & $(0.037)$ \\
Hispanic Complainant & $0.156^{* *}$ & $-0.087^{*}$ \\
BWC*Black Complainant & $(0.068)$ & $(0.047)$ \\
& $-0.162^{*}$ & -0.005 \\
BWC*Hispanic Complainant & $-0.088)$ & $(0.078)$ \\
& $(0.165$ & -0.067 \\
Number of Observations & 2,117 & $(0.101)$ \\
\hline
\end{tabular}

Notes: Robust standard errors clustered at the district level are in parentheses. ${ }^{*},{ }^{* *}$, and ${ }^{* * *}$ indicate statistical significance at the 10 percent, 5 percent, and 1 percent levels, respectively. 


\begin{tabular}{lc} 
Appendix Table1: Deployment Dates for BWCs across Chicago Police Districts \\
\hline District & Date for the Deployment of BWCs \\
\hline$\# 1$ & $03 / 10 / 2017$ \\
$\# 2$ & $06 / 29 / 2016$ \\
$\# 3$ & $11 / 06 / 2017$ \\
$\# 4$ & $07 / 09 / 2017$ \\
$\# 5$ & $11 / 20 / 2017$ \\
$\# 6$ & $08 / 04 / 2016$ \\
$\# 7$ & $05 / 01 / 2017$ \\
$\# 8$ & $10 / 02 / 2017$ \\
$\# 9$ & $08 / 18 / 2016$ \\
$\# 10$ & $07 / 25 / 2016$ \\
$\# 11$ & $07 / 05 / 2017$ \\
$\# 12$ & $12 / 03 / 2017$ \\
$\# 14$ & $06 / 01 / 2016$ \\
$\# 15$ & $06 / 13 / 2016$ \\
$\# 16$ & $11 / 20 / 2017$ \\
$\# 17$ & $11 / 20 / 2017$ \\
$\# 18$ & $03 / 29 / 2017$ \\
$\# 19$ & $10 / 30 / 2017$ \\
$\# 20$ & $10 / 23 / 2017$ \\
$\# 22$ & $10 / 30 / 2017$ \\
$\# 24$ & $10 / 16 / 2017$ \\
$\# 25$ & $12 / 04 / 2017$ \\
\hline
\end{tabular}

Note: We do not have information on the BWC deployment date for districts 13, 21, and 23. Data from these districts are excluded from the analysis. 


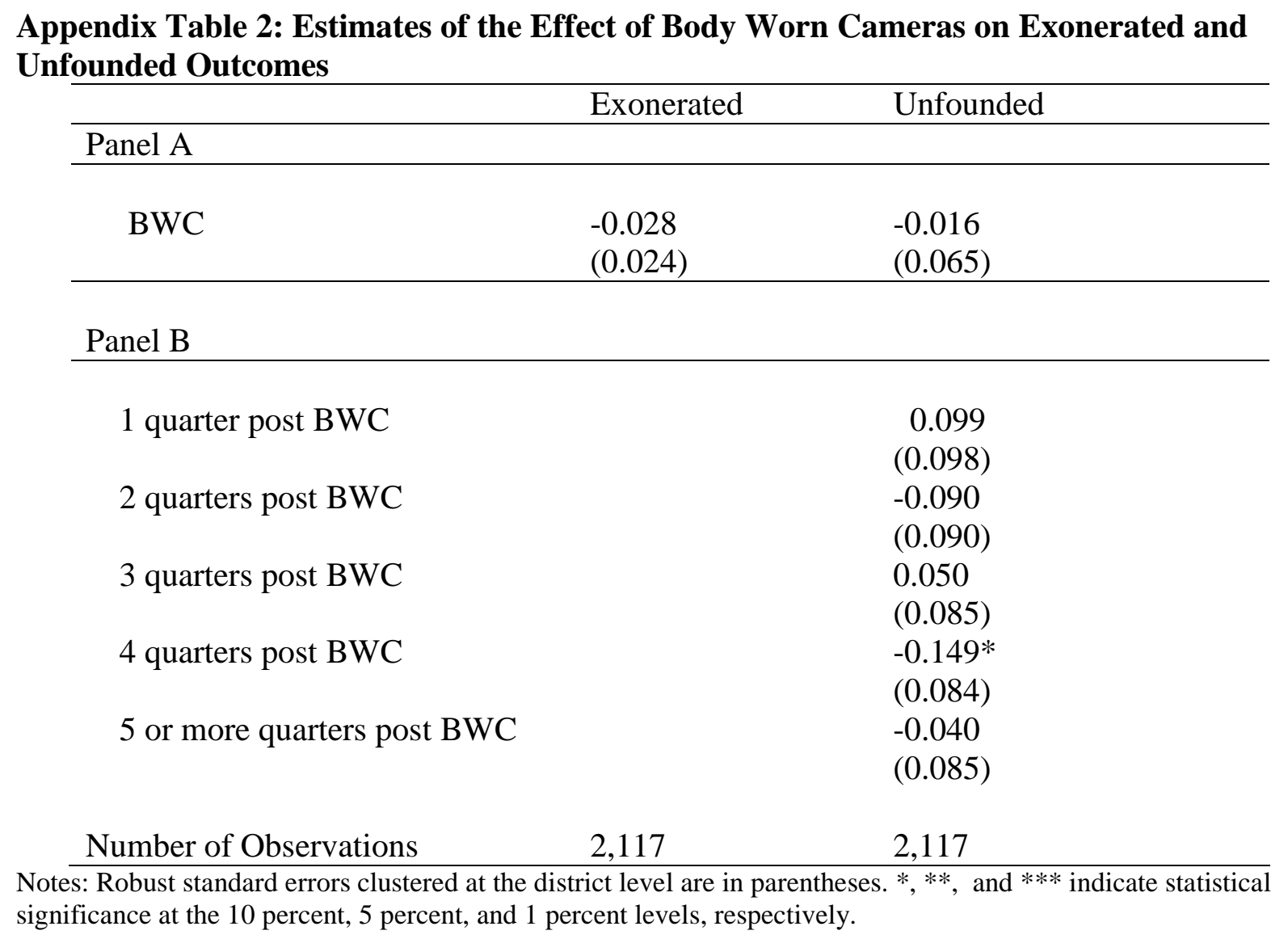

significance at the 10 percent, 5 percent, and 1 percent levels, respectively. 


\begin{tabular}{|c|c|c|}
\hline & Not Sustained & Sustained \\
\hline 5 or more quarters prior to BWC & $\begin{array}{l}-0.041 \\
(0.086)\end{array}$ & $\begin{array}{l}0.137 \\
(0.110)\end{array}$ \\
\hline 4 quarters prior to BWC & $\begin{array}{l}-0.016 \\
(0.091)\end{array}$ & $\begin{array}{l}0.051 \\
(0.096)\end{array}$ \\
\hline 3 quarters prior to BWC & $\begin{array}{l}-0.091 \\
(0.095)\end{array}$ & $\begin{array}{l}-0.020 \\
(0.073)\end{array}$ \\
\hline 2 quarters prior to BWC & $\begin{array}{l}-0.023 \\
(0.103)\end{array}$ & $\begin{array}{l}0.035 \\
(0.101)\end{array}$ \\
\hline 1 quarter post BWC & $\begin{array}{l}-0.015 \\
(0.121)\end{array}$ & $\begin{array}{l}-0.023 \\
(0.115)\end{array}$ \\
\hline 2 quarters post BWC & $\begin{array}{l}-0.149 * \\
(0.085)\end{array}$ & $\begin{array}{l}0.223^{*} \\
(0.119)\end{array}$ \\
\hline 3 quarters post BWC & $\begin{array}{l}-0.196 * * \\
(0.084)\end{array}$ & $\begin{array}{l}0.156 \\
(0.108)\end{array}$ \\
\hline 4 quarters post BWC & $\begin{array}{l}-0.026 \\
(0.089)\end{array}$ & $\begin{array}{l}0.206 * * \\
(0.094)\end{array}$ \\
\hline 5 or more quarters post BWC & $\begin{array}{l}-0.136 \\
(0.088)\end{array}$ & $\begin{array}{l}0.094 \\
(0.096)\end{array}$ \\
\hline Number of Observations & 2,117 & 2,117 \\
\hline
\end{tabular}

Notes: Robust standard errors clustered at the district level are in parentheses. * and ${ }^{* *}$ indicate statistical significance at the 10 percent and 5 percent levels, respectively. 1 quarter prior to BWC is the omitted category. 